\title{
Effect of Specimens' Shape and Size on the Determination of Compressive Strength and Deformability of Cement-lime Mortars
}

\author{
Gustavo Henrique Nalon ${ }^{a}$, Roseli Oliveira Guedes Martins ${ }^{a}$, Rita de Cássia Silva Sant'Ana Alvarenga ${ }^{a, *}$, \\ Gustavo Emilio Soares de Lima ${ }^{a}$, Leonardo Gonçalves Pedroti ${ }^{a}$, White José dos Santos ${ }^{b}$ \\ ${ }^{a}$ Universidade Federal de Viçosa - UFV, Av. Peter Henry Rolfs, s/n, Centro, CEP 36570-900, Viçosa, \\ $M G$, Brazil \\ ${ }^{b}$ Universidade Federal de Minas Gerais - UFMG, Av. Antônio Carlos, 6627, Pampulha, \\ CEP 31270-901, Belo Horizonte, MG, Brazil.
}

Received: December 12, 2016; Revised: November 20, 2017; Accepted: December 11, 2017

\begin{abstract}
This work presents comparative analyses of the effect of specimens' shape and size on the compressive strength and modulus of elasticity of mortars. Mortar mixtures with compressive strength between 5 and $20 \mathrm{MPa}$ were produced. Experimental tests determined the compressive strength of cylinder specimens of $(5 \times 10) \mathrm{cm}$ and $(10 \times 20) \mathrm{cm}$, and also cubic specimens resulted of mortar's flexural strength tests, which use $(4 \times 4 \times 16) \mathrm{cm}$ prisms. The modulus of elasticity of the cylinder specimens was also determined. Cubic specimens' compressive strength was higher than $(10 \times 20) \mathrm{cm}$ cylinder's compressive strength and lower than $(5 \times 10) \mathrm{cm}$ cylinder's compressive strength. The dimensions of the cylinder specimens influenced its compressive strength, which was higher for the $(5 \times 10) \mathrm{cm}$ specimens. However, it did not affect the static modulus of elasticity of the material. Correlations between the results were established and comparisons with different authors' results were made, improving both technological control and characterization of cement-lime mortars.
\end{abstract}

Keywords: mortar, specimens, compressive strength, modulus of elasticity.

\section{Introduction}

Cement-lime mortar is a mixture of sand, water, cement, and lime, used mainly for binding blocks or stones together, plastering, pointing, or acting as a refractory, anticorrosive or waterproofing material. The determination of the compressive strength and the modulus of elasticity of mixed lime and cement mortars in the hardened state is essential to better know the mechanical behavior of this material when used as a constructive element. Different shapes and sizes of specimens can be used to determine these properties.

To obtain the compressive strength of mortar, the Brazilian standard prescribes the use of the broken halves of $(4 \times 4 \times 16) \mathrm{cm}$ prismatic specimens, obtained from the flexural test, according to ABNT NBR 13279:2005 - Mortars applied on walls and ceilings - Determination of the flexural and the compressive strength in the hardened stage ${ }^{1}$. Prism halves are also indicated in the European standard EN 1015 - Test Methods for Masonry Mortar - Part 11: Determination of bending and compression strength of hardened mortar ${ }^{2}$. On the other hand, the American standard describes the use of $5.08 \mathrm{~cm}$ cubic specimens to determine the mortar's compressive strength in the laboratory, as prescribed by ASTM C109: Standard test method for the compressive strength of cement mortars Hydraulics ${ }^{3}$. American standards also provide instructions to obtain properties of structural masonry's

*e-mail: rcassia.alvarenga@gmail.com mortar by simulating construction site situations. In this case, cylinder specimens of $(5.08 \times 10.16 \mathrm{~cm}),(7.62 \times 15.24) \mathrm{cm}$ shall be used, as prescribed by ASTM C780: Standard Test Method for Preconstruction and Construction Evaluation of Mortars for Masonry and Reinforced Masonry ${ }^{4}$.

The Brazilian standard does not present specific procedures to determine the mortar's static modulus of elasticity by compression. For this purpose, researchers use to adjust the methodology described by ABNT NBR 8522: 2008 - Concrete - Determination of the elastic modulus of elasticity under compression $^{5}$. In this adaptation, cylindrical specimens of $(5 \times 10) \mathrm{cm}$ are used and the modulus of elasticity is calculated based on the slope of the secant straight line between the points of compressive strength of $0.5 \mathrm{MPa}$ and $30 \%$ of the material's actual ultimate strength. Dynamic tests based on wave propagation principles can also be used. These tests determine the initial tangential modulus of elasticity of the material, as described by ABNT NBR 15630: 2008 - Mortar for laying and coating of walls and ceilings - Mortars applied on walls and ceilings - Determination of the elasticity modulus by the ultrasonic wave propagation ${ }^{6}$.

A huge range of shapes and sizes of specimens can be used in the mortar's characterization. Consequently, experimental studies have been developed for years, focusing on the evaluation of the influence of the specimens' geometry on the obtained mortar properties. For example, Matthys and Singh ${ }^{7}$ investigated correlations between the 
compressive strength obtained with $5.08 \mathrm{~cm}$ cubic specimens and $(7.62 \times 15.24 \mathrm{~cm})$ cylindrical specimens. They also considered different production procedures and types of cure. For mortars produced in the laboratory and subjected to wet curing, the cylindrical specimens showed compressive strength around $80.9 \%$ of the compressive strength of the cubic specimens. For mortars produced at the construction site and subjected to air-dry curing in the laboratory, the compressive strength of cylindrical specimens was around $116.3 \%$ of the compressive strength of the cubic specimens. Schmidt ${ }^{8}$ concluded in his studies that cylindrical specimens of $(7.5 \times 15 \mathrm{~cm})$ or $(10 \times 20) \mathrm{cm}$ exhibited a compressive strength closer to the compressive strength of $5.0 \mathrm{~cm}$ cubic specimens than the compressive strength of $(5 \mathrm{x} 10) \mathrm{cm}$ cylindrical specimens. The author obtained for the cylindrical specimens a compressive strength close to $93 \%$ of the compressive strength of cubic specimens.

Most recent technical literature also shows considerable scatter between the mortar's compressive strength obtained from specimens of varying sizes and shapes. According to ASTM C780 ${ }^{4}$, the compressive strength of cylindrical specimens is close to $85 \%$ of the compressive strength of $5.08 \mathrm{~cm}$ cubic specimens. Studies developed by Parsekian et al. ${ }^{9}$ obtained, for mortars with compressive strength in the range of $4 \mathrm{MPa}$ to $12 \mathrm{MPa}$, ratios of 1.31 to 1.73 between the compressive strength of prism halves specimens and the compressive strength of $(5 \times 10) \mathrm{cm}$ cylindrical specimens. Pinheiro $^{10}$ also studied mortars with compressive strength in the range of 4 to $12 \mathrm{MPa}$, and observed that cylindrical specimens presented a compressive strength of 22 to $46 \%$ lower than the compressive strength of prism halves specimens. However, the same author pointed out an inverse behavior for mortars with compressive strength greater than the mentioned range: cylindrical specimens had compressive strength of $1 \%$ to $26 \%$ greater than cubic specimens. Lima ${ }^{11}$ also verified in his studies that cubic specimens sometimes had a lower compressive strength than cylindrical ones. At other times, their compressive strength was higher.

\section{Materials and Methods}

Five mortar compositions with estimated compressive strengths in the range of 5 to $20 \mathrm{MPa}$ were defined. Mortar specimens were produced with the Brazilian Portland cement CP II E-32, produced by Tupi S.A.; hydrated lime CHIII Supercal, produced by Ical; and natural and quartzite sand from Porto Firme, Minas Gerais, Brazil. Cement, lime, and sand basic parameters were determined according to the Brazilian standards ${ }^{12-23}$ and presented in Table 1, 2, and 3 , respectively.

Each mortar composition was produced in large volumes, in order to simulate site conditions, and used to bind structural masonry concrete blocks. At first, sand and lime were mechanically mixed with $90 \%$ of the total amount of water, during five minutes. A $120 \mathrm{~L}$ mortar mixer was used to mix the ingredients at a constant mixing speed of $30 \mathrm{rpm}$. After letting the mixture mature for approximately 24 hours, water losses were compensated, and cement and the remaining amount of water were added. A further mixture was made. Finally, the mortar's consistence index was determined according to ABNT NBR 13276:2016 -

Table 1. Portland cement properties.

\begin{tabular}{|c|c|c|c|c|}
\hline \multicolumn{2}{|c|}{ Property } & \multicolumn{2}{|c|}{ Value } & Test Method \\
\hline \multicolumn{2}{|c|}{ Density } & \multicolumn{2}{|c|}{$2.95 \mathrm{~kg} / \mathrm{dm}^{3}$} & ABNT NBR NM $23^{12}$ \\
\hline \multicolumn{2}{|c|}{ Fineness } & \multicolumn{2}{|c|}{$4.00 \%$} & ABNT NBR $11579^{13}$ \\
\hline \multirow{2}{*}{ Setting times } & Initial & \multicolumn{2}{|c|}{$2 \mathrm{~h} 30 \mathrm{~min}$} & \multirow{2}{*}{ ABNT NBR NM $65^{14}$} \\
\hline & Final & & & \\
\hline \multirow{2}{*}{ Soundness } & Cold & \multicolumn{2}{|c|}{$0 \mathrm{~mm}$} & \multirow{2}{*}{ ABNT NBR $11582^{15}$} \\
\hline & Hot & & & \\
\hline \multirow{3}{*}{ Compressive strength } & $3^{\text {th }}$ day test & $26.9 \mathrm{MPa}$ & C.V. ${ }^{*}=1.41 \%$ & \multirow{3}{*}{ ABNT NBR $7215^{16}$} \\
\hline & $7^{\text {th }}$ day test & $32.2 \mathrm{MPa}$ & C.V. $*=1.42 \%$ & \\
\hline & $28^{\text {th }}$ day test & $34.5 \mathrm{MPa}$ & C.V. $*=0.54 \%$ & \\
\hline
\end{tabular}

*C.V.: Coefficient of variation (\%)

Table 2. Hydrated lime properties.

\begin{tabular}{ccc}
\hline Property & Value & Test Method \\
\hline Density & $2.32 \mathrm{~kg} / \mathrm{dm}^{3}$ & ABNT NBR NM 23 $3^{12}$ \\
Water retention & $>70 \%$ & ABNT NBR $9290^{17}$ \\
Non-hydrated oxides & $0 \%$ & \\
Carbonic anhydride & $<10 \%$ & ABNT NBR $6473^{18}$ \\
Total oxides & $>90 \%$ & \\
\hline
\end{tabular}


Table 3. Sand properties.

\begin{tabular}{ccc}
\hline Property & Value & Test Method \\
\hline Maximum diameter & $4.8 \mathrm{~mm}$ & ABNT NBR NM $248^{19}$ \\
Fineness modulus & 2.79 & ABNT NBR NM $52^{20}$ \\
Bulk specific gravity & $2.65 \mathrm{~kg} / \mathrm{dm}^{3}$ & ABNT NBR NM $45^{21}$ \\
Unit weight & $1.40 \mathrm{~kg} / \mathrm{dm}^{3}$ & ABNT NBR NM $46^{22}$ \\
Material finer than $75 \mu \mathrm{m}$ sieve & $0.90 \%$ & ABNT NBR NM $30^{23}$ \\
Water absorption & $0.80 \%$ & \\
\hline
\end{tabular}

Mortars applied on walls and ceilings - Determination of the consistence index ${ }^{24}$.

Table 4 shows the different mortar compositions and some environmental conditions measured during their production. It also presents their consistence indexes, which are close to the recommended range for structural masonry's mortar: $(230 \pm 10) \mathrm{mm}$.

For each mortar composition, the most used specimens' shape and sizes were produced:

- $\quad \operatorname{six}(4 \times 4 \times 16) \mathrm{cm}$ prismatic specimens. The mold was filled in two layers. After placing each layer, the mold was placed on the flow table, which dropped 30 times within a period of 30 seconds.

- four $(5 \times 10) \mathrm{cm}$ cylindrical specimens. The mold was filled in four layers. For consolidation, the rod penetrated through each layer 30 times.

- four $(10 \times 20) \mathrm{cm}$ cylindrical specimens. A 10 seconds vibration time was applied to consolidate the mortar in the molds.

All of the specimens were subjected to a similar curing process, in a moist room at a temperature of $(23 \pm 2)^{\circ} \mathrm{C}$ and relative humidity of $95 \%$. Initially, they were left inside their molds during two days. After that, they were demolded and allowed to cure in air during 26 days. After this period of time, the following tests were performed:

A) Flexural strength test: in order to determine the indirect tensile strength of the mortar, load was applied to the $(4 \times 4 \times 16) \mathrm{cm}$ prism specimens as shown in Figure 1, until its rupture. This method is prescribed by ABNT NBR 13279:2005'.

B) Compressive strength test with prism halves specimens: each half of the prismatic specimen was placed between two $(4 \times 4 \times 1) \mathrm{cm}$ steel plates, as shown in Figure 1. The compressive load was increased at a rate of $550 \mathrm{~N} / \mathrm{s}$, until the rupture. The maximum supported load was used to calculate the compressive strength of the material. When discussing the results, the value obtained was considered the compressive strength of a $4.0 \mathrm{~cm}$ cubic specimen, based on the dimensions of the steel plates used.

C) Compressive strength test with cylindrical specimens: $(5 \times 10) \mathrm{cm}$ and $(10 \times 20) \mathrm{cm}$ sulfurcapped cylindrical specimens were subjected to the uniaxial compression test in the EMIC press, PC $200 \mathrm{C}$ series, equipped with an oscillating top plate. The loading rate was around $0.30 \mathrm{MPa} / \mathrm{s}$.

D) Static modulus of elasticity of cylindrical specimens: an uniaxial load was applied to the $(5 \times 10) \mathrm{cm}$ and $(10 \times 20) \mathrm{cm}$ sulfur-capped cylindrical specimens in the EMIC press, PC $200 \mathrm{C}$ series, as shown in Figure 2. The applied load was recorded by load cells of the testing machine. The longitudinal strain of the specimens was measured by EMIC clip gauges. An automated test method performed loading and unloading cycles according to the procedures described by ABNT NBR 8522:20085. The modulus of elasticity was calculated between the points of compressive stress of $0.5 \mathrm{MPa}$ and $30 \%$ of the ultimate stress.

\section{Results and Discussion}

Tables 5, 6, and 7 present the results of the mechanical characterization tests of the different kinds of mortars specimens.

Table 4. Mortar compositions and environmental conditions during its production.

\begin{tabular}{ccccccccc}
\hline Mortar & PC : lime : sand (mass) & Water/ cement ratio & $\begin{array}{c}\text { Humidity } \\
(\%)\end{array}$ & $\begin{array}{c}\text { Temperature } \\
\left({ }^{\circ} \mathrm{C}\right)\end{array}$ & D1 & D2 & D3 & Mean \\
\hline T1 & $1.00: 0.45: 7.48$ & 1.49 & 70 & 26.1 & 218 & 216 & 221 & 218 \\
T2 & $1.00: 1.32: 6.06$ & 1.43 & 79 & 20.0 & 223 & 225 & 229 & 226 \\
T3 & $1.00: 0.32: 5.25$ & 1.07 & 79 & 26.0 & 212 & 210 & 215 & 212 \\
T4 & $1.00: 0.88: 4.49$ & 1.14 & 71 & 19.0 & 235 & 240 & 244 & 240 \\
T5 & $1.00: 0.20: 3.39$ & 0.74 & 72 & 26.3 & 230 & 233 & 228 & 231 \\
\hline
\end{tabular}



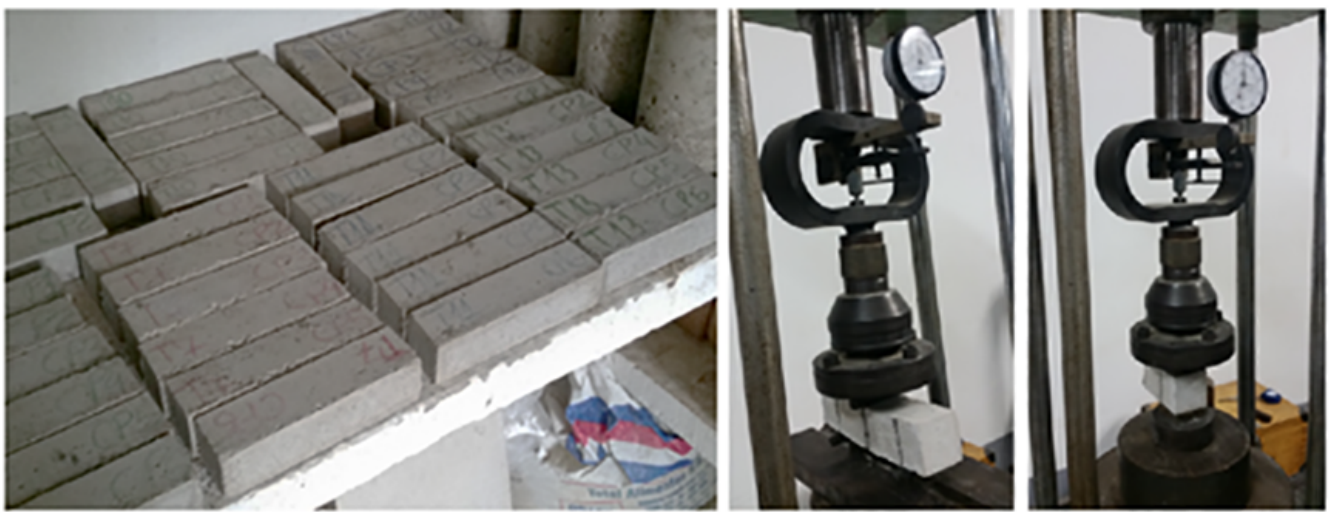

Figure 1. Flexural and compressive strength tests with $(4 \times 4 \times 16) \mathrm{cm}$ prism specimens.
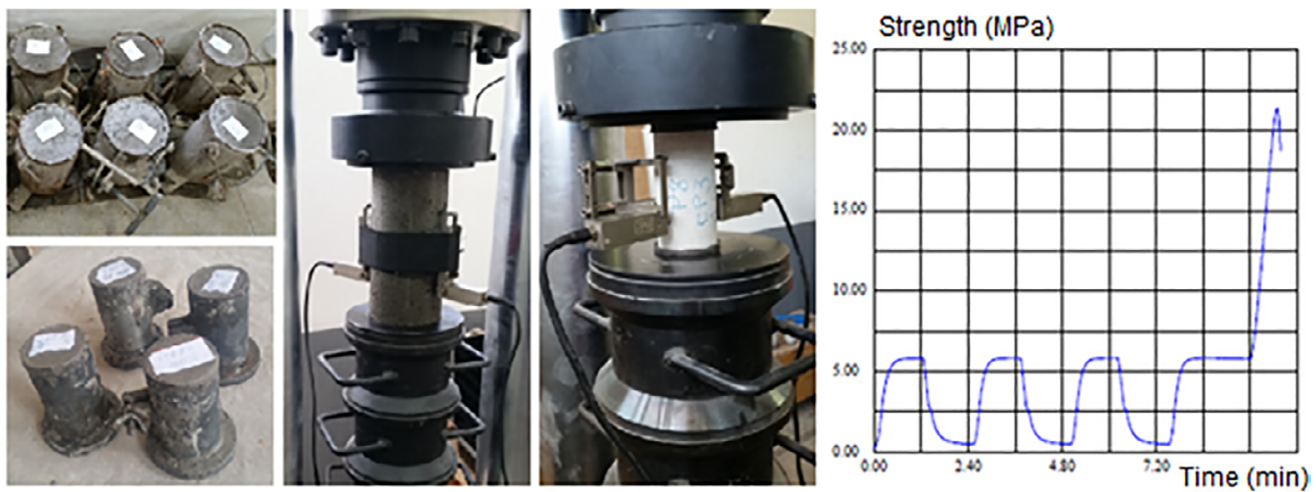

Figure 2. Determination of compressive strength and modulus of elasticity of cylindrical specimens.

Table 5. Results of ( $4 \times 4 \times 16) \mathrm{cm}$ prism specimens.

\begin{tabular}{|c|c|c|c|c|c|c|c|c|}
\hline \multirow[b]{2}{*}{ Mortar } & \multicolumn{4}{|c|}{ Indirect tensile strength $f_{t}$} & \multicolumn{4}{|c|}{ Compressive strength $f_{c}$} \\
\hline & $\begin{array}{l}\text { Number of } \\
\text { specimens }\end{array}$ & $\begin{array}{l}f_{\text {taverage }} \\
\text { (MPa) }\end{array}$ & $\begin{array}{c}\text { Standard } \\
\text { deviation } \\
(\mathrm{MPa})\end{array}$ & $\begin{array}{l}\text { Coefficient } \\
\text { of variation } \\
(\%)\end{array}$ & $\begin{array}{l}\text { Number of } \\
\text { specimens }\end{array}$ & $\begin{array}{l}f_{\text {caverage }} \\
\text { (MPa) }\end{array}$ & $\begin{array}{c}\text { Standard } \\
\text { deviation } \\
(\mathrm{MPa})\end{array}$ & $\begin{array}{c}\text { Coefficient } \\
\text { of variation } \\
(\%)\end{array}$ \\
\hline $\mathrm{T} 1$ & 6 & 1.7 & 0.15 & 9.12 & 12 & 5.9 & 0.41 & 6.85 \\
\hline $\mathrm{T} 2$ & 6 & 2. 6 & 0.01 & 0.15 & 12 & 7.0 & 0.42 & 6.11 \\
\hline $\mathrm{T} 3$ & 6 & 3.0 & 0.33 & 10.74 & 12 & 9.4 & 0.91 & 9.76 \\
\hline $\mathrm{T} 4$ & 6 & 2.9 & 0.32 & 11.11 & 12 & 10.4 & 0.31 & 2.93 \\
\hline $\mathrm{T} 5$ & 6 & 4.8 & 0.37 & 7.70 & 12 & 17.1 & 1.18 & 6.90 \\
\hline
\end{tabular}

Table 6. Results of $(5 \times 10) \mathrm{cm}$ cylindrical specimens.

\begin{tabular}{cccccccccc}
\hline & \multicolumn{3}{c}{ Compressive strength $f_{c}$} \\
Mortar & $\begin{array}{c}\text { Number of } \\
\text { specimens }\end{array}$ & $\begin{array}{c}f_{\text {caverage }} \\
(\mathrm{MPa})\end{array}$ & $\begin{array}{c}\text { Standard } \\
\text { deviation } \\
(\mathrm{MPa})\end{array}$ & $\begin{array}{c}\text { Soefficient } \\
\text { of variation } \\
(\%)\end{array}$ & $\begin{array}{c}\text { Number of } \\
\text { specimens }\end{array}$ & $\begin{array}{c}E_{\text {maverage }} \\
(\mathrm{GPa})\end{array}$ & $\begin{array}{c}\text { Standard } \\
\text { deviation } \\
(\mathrm{GPa})\end{array}$ & $\begin{array}{c}\text { Coefficient } \\
\text { of variation } \\
(\%)\end{array}$ \\
\cline { 2 - 10 } T1 & 3 & 5.8 & 0.10 & 1.70 & 3 & 9.5 & 0.60 & 6.38 \\
T2 & 3 & 7.1 & 0.31 & 4.29 & 3 & 12.1 & 2.44 & 20.12 \\
T3 & 3 & 11.1 & 0.86 & 7.75 & 3 & 14.0 & 0.37 & 2.65 \\
T4 & 3 & 12.2 & 0.55 & 4.53 & 3 & 14.2 & 0.75 & 5.24 \\
T5 & 3 & 20.7 & 0.73 & 3.55 & 3 & 19.4 & 0.42 & 2.18 \\
\hline
\end{tabular}




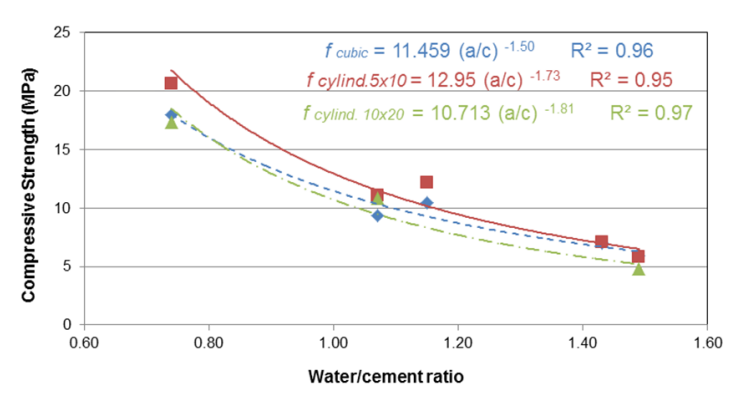

Figure 3. Curves of compressive strength - water/cement ratio for different kinds of specimen, for mortars with compressive strength in the range of 5 to $20 \mathrm{MPa}$.
The reduction in the compressive strength with the increase of the water/cement ratio was slightly different for each kind of specimen. Experimental results allowed the construction of curves and equations that represent a good correlation between mortar's compressive strength and water/ cement ratio. Figure 3 shows these curves, equations, and their corresponding coefficient of determination $\mathrm{R}^{2}$ for the different types of specimens tested. The experimental data strongly fit the defined curves, so the correlation coefficient was very close to 1.0 in all of the cases.

Experimental results show that for any kind of mortar composition, the compressive strength of $(5 \times 10) \mathrm{cm}$

Table 7. Results of $(10 \times 20) \mathrm{cm}$ cylindrical specimens.

\begin{tabular}{cccccccccc}
\hline \multirow{3}{*}{ Mortar } & \multicolumn{3}{c}{ Compressive strength $f_{c}$} & \multicolumn{5}{c}{ Static modulus of elasticity $E_{m}$} \\
& $\begin{array}{c}\text { Number of } \\
\text { specimens }\end{array}$ & $\begin{array}{c}f_{\text {caverage }} \\
(\mathrm{MPa})\end{array}$ & $\begin{array}{c}\text { Standard } \\
\text { deviation } \\
(\mathrm{MPa})\end{array}$ & $\begin{array}{c}\text { Coefficient } \\
\text { of variation } \\
(\%)\end{array}$ & $\begin{array}{c}\text { Number of } \\
\text { specimens }\end{array}$ & $\begin{array}{c}E_{\text {maverage }} \\
(\mathrm{GPa})\end{array}$ & $\begin{array}{c}\text { Standard } \\
\text { deviation } \\
(\mathrm{GPa})\end{array}$ & $\begin{array}{c}\text { Coefficient } \\
\text { of variation } \\
(\%)\end{array}$ \\
\cline { 2 - 10 } T1 & 3 & 4.8 & 0.03 & 0.68 & 3 & 9.6 & 0.77 & 8.02 \\
T3 & 3 & 10.8 & 0.89 & 8.21 & 3 & 15.2 & 0.20 & 1.33 \\
T5 & 3 & 17.3 & 0.75 & 4.35 & 3 & 18.9 & 0.86 & 4.54 \\
\hline
\end{tabular}
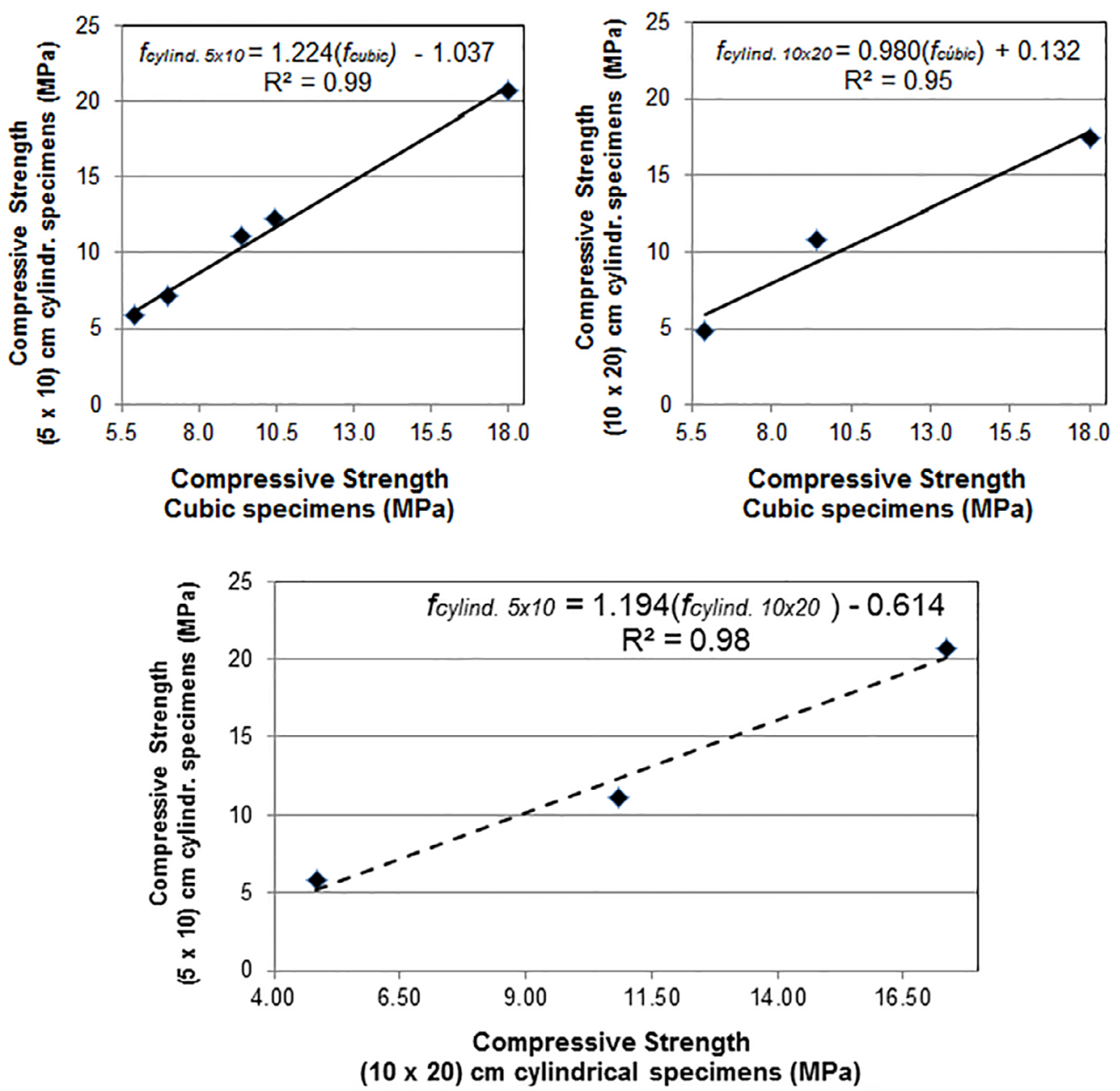

Figure 4. Correlations between compressive strength of specimens of different shapes and sizes. 

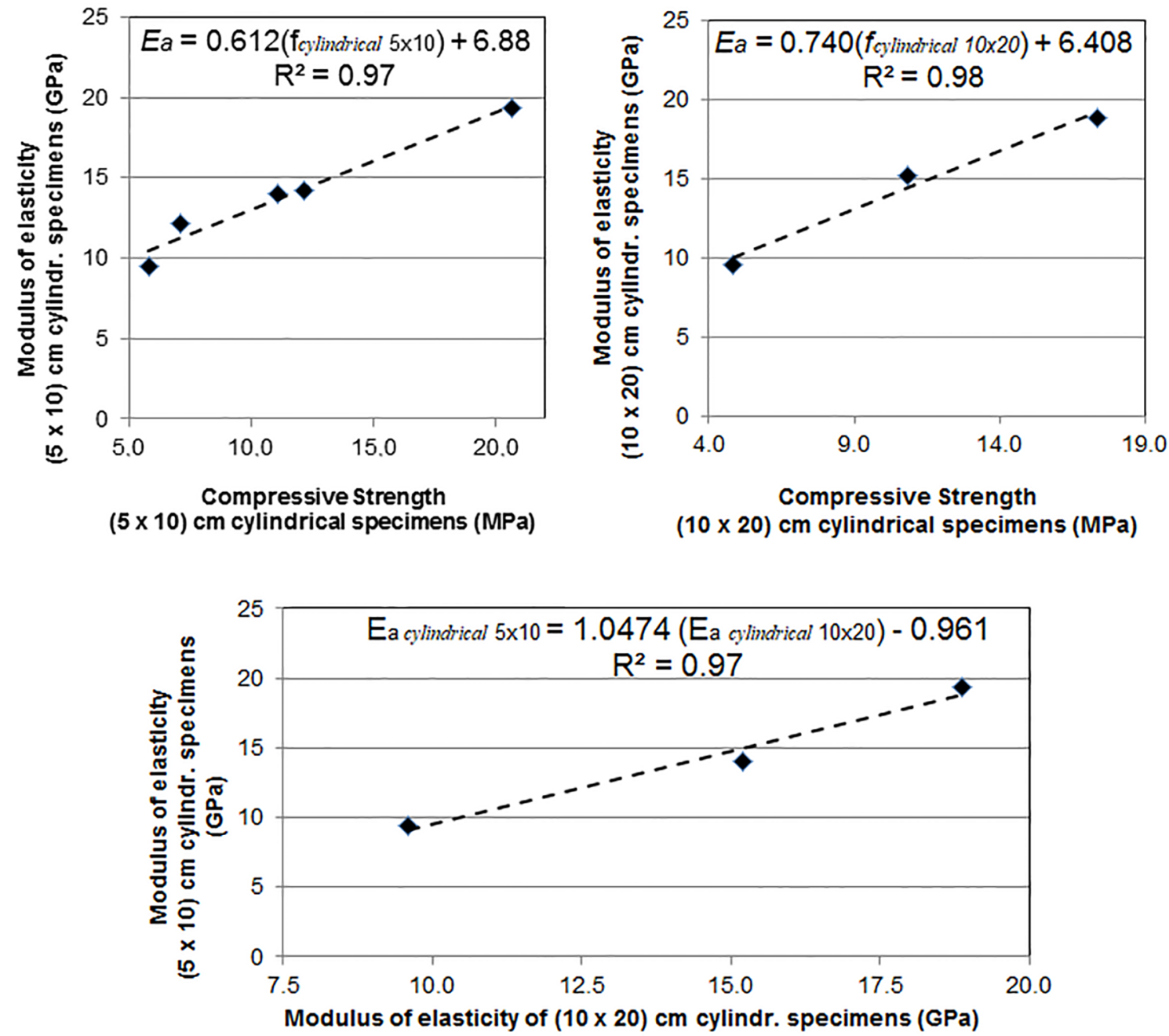

Figure 5. Correlations between compressive strength and modulus of elasticity of cylindrical specimens of different sizes.

cylindrical specimens exceeded the compressive strength of $(10 \times 20) \mathrm{cm}$ cylindrical specimens. For high strength mortars, the compressive strengths of cubic and $(10 \times 20) \mathrm{cm}$ cylindrical specimens were pretty close, as also observed by $\mathrm{Schmidt}^{8}$. However, for weaker mortars, the cylindrical specimens showed compressive strength closer to the compressive strength obtained for the cubic ones.

On the other hand, the relationship between the compressive strength of $(5 \times 10) \mathrm{cm}$ cylindrical and cubic specimens was very similar to the behavior found by Matthys and Singh ${ }^{7}$, for mortars produced at the construction site and subjected to air-dry curing in the laboratory, which was the same process developed in the experimental program performed in this research. In this case, cylindrical specimens presented a compressive strength greater than the cubic ones.

Figure 4 presents correlations between the compressive strengths obtained for different shapes and sizes of specimen. A simple linear regression proved to be effective in each established correlation. The obtained correlations coefficients are pretty close to 1.0 , which shows a strong positive linear correlation between the parameters.

Figure 5 presents correlations between the compressive strength and the static modulus of elasticity of the cylindrical specimens. It also shows a correlation between the modulus of elasticity determined for the two kinds of cylindrical specimens. A simple linear regression was the most adequate correlation, since the coefficients of determination are again very close to 1.0. Very similar curves were obtained for the different sizes of specimens. This behavior is in agreement with that observed by Brooks ${ }^{25}$ : the size of the specimen does not affect its modulus of elasticity.

\section{Conclusions}

The compressive strength of cubic specimens was higher than the compressive strength of $(10 \times 20) \mathrm{cm}$ cylindrical specimens and lower than the compressive strength of ( $5 \times 10) \mathrm{cm}$ cylindrical ones. The dimensions of the cylindrical specimens greatly influenced their compressive strength, 
which was larger for those of dimensions $(5 \times 10) \mathrm{cm}$, but did not affect the static modulus of elasticity of the material. Based on the large discrepancy of results available in the literature regarding this subject, the present work contributed to the optimization of the technological control of mixed cement-lime mortars, when analyzing the effect of different shapes and sizes of specimens in the determination of mortar's compressive strength and modulus of elasticity, establishing correlations between the results, and comparing them with those obtained by different authors.

\section{Acknowledgements}

The authors thank the Brazilian agencies: National Counsel of Technological and Scientific Development (CNPq), Coordination for the Improvement of Higher Education Personnel (CAPES) and Research Support Foundation of Minas Gerais (FAPEMIG) for the support provided to this study.

\section{References}

1. Brazilian Association of Technical Norms (ABNT). NBR 13279 - Mortar - Determination of the compressive strength in the hardened stage - Method of test. Rio de Janeiro: ABNT; 2005.

2. European Committee for Standardization. CEN EN 1015 - Methods of Test for Mortar for Masonry - Part 11: Determination of flexural and compressive strength of hardened mortar. Brussels: European Committee for Standardization; 2007.

3. ASTM International. ASTM C109 / C109M-16a - Standard Test Method for Compressive Strength of Hydraulic Cement Mortars (Using 2-in. or [50-mm] Cube Specimens). West Conshohocken: ASTM International; 2016.

4. ASTM International. ASTM C780-15a-Standard Test Method for Preconstruction and Construction Evaluation of Mortars for Plain and Reinforced Unit Masonry. West Conshohocken: ASTM International; 2015.

5. Brazilian Association of Technical Norms (ABNT). NBR 8522 - Concrete - Determination of the static elasticity and deformation modulus. Rio de Janeiro: ABNT; 2008.

6. Brazilian Association of Technical Norms (ABNT). NBR 15630 - Mortars applied on walls and ceilings - Determination of the elasticity modulus by the ultrasonic wave propagation. Rio de Janeiro: ABNT; 2008.

7. Matthys JH, Singh R. Experimental Investigation of Mortar Compressive Strength Using $5.08 \mathrm{~cm}$ Cubes and $7.62 \mathrm{~cm} \mathrm{x}$ $15.24 \mathrm{~cm}$ Cylinders. In: Matthys JH, ed. Masonry: Components to Assemblages. Philadelphia: ASTM; 1990. p. 194-205.

8. Schmidt S, Brown ML, Tate R. Quality Control of Mortars: Cubes vs. Cylinders. In: Matthys JH, ed. Masonry: Components to Assemblages. Philadelphia: ASTM STP 1063, 1990. p. 147163.
9. Parsekian GA, Fonseca FS, Pinheiro GL, Camacho JS. Properties of Mortar Using Cubes, Prism Halves, and Cylinder Specimens. Materials Journal. 2014;111(4):443-454.

10. Pinheiro GL. Propriedades de argamassas para alvenaria estrutural: estudo de caso e experimental. [Completion of Coursework]. São Carlos: Universidade Federal de São Carlos; 2011. $83 \mathrm{f}$.

11. Lima JS. Análise da influência do capeamento e da geometria de corpos-de-prova na resistência à compressão de argamassas. [Completion of Coursework]. Caruaru: Universidade Federal de Pernambuco; 2013. $58 \mathrm{f}$.

12. Brazilian Association of Technical Norms (ABNT). NBR NM 23 - Portland cement and other powdered material - Determination of density. Rio de Janeiro: ABNT; 2000.

13. Brazilian Association of Technical Norms (ABNT). NBR 11579 - Portland cement - Determination of fineness by the $75 \mu \mathrm{m}\left(n^{\circ}\right.$ 200) sieve - Method of test. Rio de Janeiro: ABNT; 2013.

14. Brazilian Association of Technical Norms (ABNT). NBR NM 65 - Portland cement - Determination of setting times. Rio de Janeiro: ABNT; 2003.

15. Brazilian Association of Technical Norms (ABNT). NBR 11582 - Portland cement - Determination of soundness by the Le Chatelier method - Method of test. Rio de Janeiro: ABNT; 2012.

16. Brazilian Association of Technical Norms (ABNT). NBR 7215 - Portland cement - Determination of compressive strength. Rio de Janeiro: ABNT; 1996. Corrected version: 1997.

17. Brazilian Association of Technical Norms (ABNT). NBR 9290 - Hydrated lime for mortars - Determination of water retention - Method of test. Rio de Janeiro: ABNT; 1996.

18. Brazilian Association of Technical Norms (ABNT). NBR 6473 - Caustic lime and hydrated lime - Chemical analysis. Rio de Janeiro: ABNT; 2003.

19. Brazilian Association of Technical Norms (ABNT). NBR NM 248 - Aggregates - Sieve analysis of fine and coarse aggregates. Rio de Janeiro: ABNT; 2003.

20. Brazilian Association of Technical Norms (ABNT). NBR NM 52 - Fine aggregate - Determination of the bulk specific gravity and apparent specific gravity. Rio de Janeiro: ABNT; 2002.

21. Brazilian Association of Technical Norms (ABNT). NBR NM 45 - Aggregates - Determination of the unit weight and air-void contents. Rio de Janeiro: ABNT; 2006.

22. Brazilian Association of Technical Norms (ABNT). NBR NM 46 - Aggregates - Determination of material finer than $75 \mu \mathrm{m}$ sieve by washing. Rio de Janeiro: ABNT; 2003.

23. Brazilian Association of Technical Norms (ABNT). NBR NM 30 - Fine aggregate - Test method for water absorption. Rio de Janeiro: ABNT; 2001.

24. Brazilian Association of Technical Norms (ABNT). NBR 13276 - Preparation of mortar for unit masonry and rendering with standard consistence index. Rio de Janeiro: ABNT; 2005.

25. Brooks JJ. Concrete and Masonry Movements. $1^{\text {st }}$ ed. Oxford: Butterworth Heinemann; 2015. 599 p. 